\title{
NEW ANTS OF THE GENUS MACROMISCHA
}

\author{
By C. G. Aguayo \\ Museum of Comparative Zoölogy
}

The ants of the remarkable genus Macromischa, besides being among the most beautifully colored of the Formicoidea, are certainly very interesting on account of their extremely localized habitat.

W. M. Wheeler in a recent paper on this genus (1931) has described several new forms, among which were several Cuban species that I had the pleasure of sending to him. As I still have some undescribed new varieties recently collected by Dr. Pedro Bermudez, Colonel George Natenzon and myself, I avail myself of the opportunity given me by the Guggenheim Memorial Foundation to study in the United States, and Dr. Barbour's permission to work in the Museum of Comparative Zoölogy, to publish this small contribution to the knowledge of Cuban ants.

Wheeler raised to generic rank (1931, p. 4), the subgenera Crœsomyrmex and Antillæmyrmex, both of Mann (1920, p. 408), but since among the species described further on Macromischa wheeleri petri shows intermediate characteristics between Macromischa s.s. and Crœsomyrmex, he agrees with me in placing them anew as subgenera.

The position of Antillæmyrmex as a genus was more uncertain on account of the intermediate characters shown by some species (Wheeler, loc. cit. p. 4), and it seems to be convenient to consider it again as a subgenus.

I cannot but thank Prof. Wheeler and Dr. Bequaert for their many helpful suggestions during the preparation of this paper. 
Macromischa barbouri sp. nov.

Worker. Length $4 \mathrm{~mm}$.

Head (without mandibles) about $1 / 4$ longer than broad, suboval, with rounded posterior corners, broader behind, sides convex. Eyes rather large, oval, situated at the middle of the sides of the head. Mandibles with five distinct teeth. Clypeus convex, with a distinct short and narrow longitudinal carina. Frontal carinæ short. Antennæ somewhat stout, scapes strongly curved at base, surpassing the occipital corners; first funicular joint as long as the two succeeding joints, joint two larger than broad, joints 3-7 slightly transverse. Club 3-jointed, well defined, last joint about as long as the two preceding together.

Thorax stout, less than twice as long as broad, humeri of pronotum large, with rounded angles. No thoracic sutures. Epinotal spines slender, divergent, almost straight, slightly curved downward, about 3.5 times as long as their distance apart at base.

Pedicel long and slender, about as long as the epinotal spines, and three times as long as the node; acutely toothed antero-ventrally. Node in profile about twice as high as long, compressed antero-posteriorly, anterior surface moderately convex, posterior flat; from above two and one-half times broader than long; the upper border twice as broad as the base. Post-petiole in profile decidedly longer than the petiolar node; anterior surface straight, broadly rounded; from above sub-campanulate, about $11 / 5$ times as broad as long. Gaster with the first segment slightly longer than broad.

Legs stout, femora strongly swollen at the middle; tibiæ rather incrassated.

Thorax, gaster and appendages very shiny; head moderately so. Mandibles and clypeus coarsely, longitudinally striated. Head minutely and densely punctate, with sinuous longitudinal, interrupted rugæ. Thorax coarsely rugose, the rugæ being transversely irregularly sinuous on dorsum, longitudinally sinuous on pleuræ, and transverse 
on epinotal declivity. Petiole, postpetiole, gaster and legs minutely punctate.

Hairs white, stiff, erected, moderately abundant, longer on thorax.

Head green, thorax red, with violaceous and greenish reflections in certain lights. Epinotal spines brownish red. Pedicel, base of femora and tip of tarsi yellowish brown. Petiolar node, post-petiole, gaster, remaining of legs and antennæ black.

Described from a single specimen collected by Colonel G. Natenzon in "Pan de Guajaibon," province of Pinar del Rio, Cuba.

Holotype in the collection of the M. C. Z.

This species is related to $M$. squamifera Roger and $M$. creightoni Mann, but readily distinguishable by the longer epinotal spines, coarser sculpture and by the red coloration of the thorax.

It is with pleasure that I name this species for Dr. Thomas Barbour, to whom I am very much indebted for many favors.

Macromischa manni Wheeler var. villarensis var. nov.

Worker. Length 5.2 to $5.8 \mathrm{~mm}$.

This form has the same size, sculpture and pilosity as $M$. manni, differing principally by the shape and position of the epinotal spines which in var. villarensis are somewhat smaller, much more divergent, V-shaped, closer together at their bases, lacking the sigmoidal curve of manni, directed backward, upward and slightly bent inward at their tips; the basal half of each spine is broader and laterally compressed, the dilatation ending abruptly at the middle as in $M$. porphyritis var. latispina Wheeler.

Described from many specimens collected by Pedro Bermudez in several localities of Northern Santa Clara, Cuba. They were on limestone cliffs, "with the gaster bent and upraised" (Bermudez).

Type locality: "La Puntilla," Remedios, Santa Clara, Central Cuba. 
Also from "Palenque de Taguayabon" in the same region. Named for "Las Villas," a popular name for the said region.

Cotypes in the M. C. Z. and in the author's collection.

Macromischa (Antillæmyrmex) torrei sp. nov.

Worker. Length $2 \mathrm{~mm}$.

Head longer than broad, rectangular, with evenly convex sides, straight posterior border and rounded occipital corners. Eyes convex, situated before the middle of the sides of the head. Clypeus convex, with rounded anterior border. Frontal carinæ parallel. Frontal area indistinct. Mandibles with denticulate, concave apical border. Antennal scapes scarcely reaching the posterior corners of the head; funicular club large, 3-jointed, longer than the remaining funiculus; joint 2-7 broader than long.

Thorax short, as long as the head with mandibles, broader in front than behind, with regular slightly convex profile, without dorsal thoracic sutures. Epinotal spines about as long as the epinotal declivity, and longer than their distance at the base, directed backward and upward, and very slightly curved downward.

Peduncle short, with a small tooth on its anteroventral surface. Node longer than broad; its anterior declivity in profile slightly concave, its summit flattened, and its posterior declivity almost straight. Postpetiole large, twice as broad as long, almost as broad as the gaster, and three times as broad as the petiole behind, in profile convex above. Gaster small, about as long as the thorax.

Legs small, femora feebly incrassated.

Surface of body shining, head and thorax densely and finely punctate. Gaster smooth. Appendages very finely punctate and shining.

Pilosity scarce. Hairs white, short, erected and scattered on the body; minute on scapes and legs.

Color uniformly testaceous.

Described from one specimen found alive among land shells given to me by Dr. Carlos de la Torre, and it is a 
great honour to me to associate his name with this interesting species. The shells were collected by Bermudez in "Buenavista," Remedios, Santa Clara Province, Cuba.

The holotype is deposited in the M. C. Z.

This small species is typically an Antillæmyrmex and similar in size and coloration to $M$. flavidula Wheeler and Mann from Hayti, but it is very easily separated by its sculpture, shape of petiolar node, shape of the head, position of eyes, etc. It can not be confused with any other species of this genus.

\section{Macromischa (Crœsomyrmex) aguayoi natenzoni}

subsp. nov.

Worker. Length $3.6 \mathrm{~mm}$.

This subspecies is very closely related to the typical form, but differs by the punctations of the head, which are more abundant in the occipital region; by the less shiny surface of the head, and by the sculpture of the thorax. The thoracic rugæ are longitudinally and regularly disposed both on sides and dorsum, instead of being regularly longitudinal on sides, coarse and irregularly longitudinal on pronotum, irregular on meso and epinotum and transverse on epinotal declivity, as occurs in the typical aguayoi.

The color is blue as in the typical form the head being slightly greenish.

Described from one specimen given to me by G. Natenzon, who collected it on a limestone cliff at Guajaibon, the highest mountain in the province of Pinar del Rio, Cuba.

The holotype is in the M. C. Z.

\section{Macromischa (Crœsomyrmex) barroi sp. nov.}

Worker. Length $4 \mathrm{~mm}$.

Head longer than broad, with rounded occipital corners. Eyes situated at the middle of the sides of the head. Mandibles 5-toothed, with slightly convex external margin. Clypeus convex posteriorly and impressed at middle. Frontal carinæ slightly divergent. Frontal area deeply 
impressed, with a median carinula. Antennæ slender, scapes extended far beyond the occipital corners, first funicular segment as long as the two following together; all the remainder longer than broad; club 13-jointed.

Thorax about 2.2 times as long as broad, broadest at the pronotum. Meso- and epinotum roof-shaped.

Peduncle of petiole short and stout, shorter than node, with a distinct antero-ventral tooth, very convex above, evenly concave below. Node broader than petiole, evenly curved both in front and behind. Post-petiole slightly longer than broad.

Legs long; femora strongly incrassated.

Surface of the body entirely shining. Scapes finely striated; head densely punctate, except the occipital border and corners; cheeks and mandibles rugose. Thorax rugose; rugæ longitudinal on sides, irregularly longitudinal on pronotum and mesonotum and transverse on epinotal declivity. Sides of petiole with radiating rugæ. Post-petiole, gaster and legs smooth. Hairs white, pointed, erected, scattered over the body and appendages.

Head, thorax and petiole deep metallic green. Head with bluish reflections. Post-petiole, gaster and appendages black.

Described from several specimens found on limestone cliffs at "Soroa," Province of Pinar del Rio, Western Cuba. (Aguayo, coll. IV 1931). Numerous specimens which I refer to this form were taken at "El Mamey," Cayajabos, Pinar del Rio, on limestone cliffs, by P. Bermudez, M. Jaume and G. Aguayo.

Cotypes of this species are in the M. C. Z. and in the author's collection.

I have named this form for my friend M. Barro, an amateur entomologist.

This species belongs to the group of $M$. aguayo $i$ to which it is very closely related, but it can be separated by the following characters: thorax broader; pedicel higher, much more convex above and more evenly concave below; petiolar node longer than broad and more evenly curved in front; head less densely punctate on the posterior half. Sculpture 
of thorax different. Pilosity more abundant, hairs shorter and stiffer. Coloration different. Gaster and post-petiole less shining.

Agrees with $M$. aguayoi var. archeri Wheeler in the punctation of the head and shape of the post-petiole, but differs by the shape of the petiole, sculpture of the thorax, pilosity and color.

Santschi recently described (1931), another species of this group: $M$. bierigi, which comes from "Vinales" the type locality for archeri, but the description of bierigi agrees so much with the cotypes of archeri that I have examined, that if not the same it is only a variety of $M$. aguayoi very close to archeri.

Macromischa wheeleri petri subsp. nov.

Worker. Length $4.5 \mathrm{~mm}$.

Head longer than broad, sides slightly convex, posterior corners rounded. Eyes situated at the middle of the sides of the head. Mandibles with 5 teeth. Frontal carinæ short and slightly divergent behind. Antennæ slender, scapes surpassing the occipital corners, first funicular joint slightly longer than broad, club 3-jointed, terminal joint a little shorter than the two preceding together. Clypeus rounded, anterior border concave.

Thorax about $21 / 2$ times as long as broad, epinotum armed with a pair of short blunt divergent spine-like tubercles, which are much shorter than their distance at base.

Peduncle of petiole curved, as long as node, with a small blunt tooth beneath in front. Node in profile as long as high, convexly rounded above. Post-petiole campanulate, about as long as broad. Femora incrassated, tibiæ somewhat so.

Body and appendages very shining. Head with sparse piligerous punctures.

Mandibles and cheeks triated, scapes finely so. Thorax and epinotum coarsely rugose. Rugæ sinuous on pronotum, transverse on meso- and epinotum. Petiole longitudinally rugose at sides. 
Body and appendages with sparse erected white hairs.

Color of body dark brilliant green.

Described from many workers found in several localities of Santa Clara, Central Cuba, by Pedro Bermudez. "They were found walking on big limestone rocks apparently nesting under them."

Type locality: "La Vigia," Mayajigua, Santa Clara.

The cotypes are in the M. C. Z. and in the author's collection.

I have also specimens from "El Yigre," Caibarién; Seibabo de Yaguajay, and Chambas.

Named for my friend Pedro Bemudez, its discoverer.

This form is very remarkable on account of the short epinotal spines, which show a transition between the subgenera Macromischa s.s. and Croesomyrmex. The presence of spines is characteristic of the former, but all the remaining characters are those of $M$. wheeleri, which is the genotype of Croesomyrmex.

The female of wheeleri has also short epinotal spines, and it is to be noted that intermediate characters have been found in a form of the type species of Croesomyrmex.

Differs from the typical form of the species by the presence of epinotal spines, and by its color which is more deeply green. In all the specimens of wheeleri in the collection of M. C. Z., the color is brownish green.

Macromischa foreli nom. nov.

Macromischa petiolata (Forel). Emery, Genera Insectorum, 1920, p. 245 (nec M. petiolata Mayr, 1868).

Macromischa petiolata Wheeler, Bull. M. C. Z. 72, 1, 1931.

Leptothorax petiolatus Forel, Ann. Soc. Ent. Bel. 45, 1901, p. 229.

This species was described by Forel as Leptothorax petiolatus, in 1901, from specimens collected by Wheeler at "Cuernavaca," Morelos, Mexico, with the suggestion that it might be considered as a Macromischa. Emery (1920) 
transfers it to the said genus, an opinion accepted by Wheeler (1931). Unfortunately the name was preoccupied by Macromischa petiolata Mayr (1868, "Die Ameisen des baltischen Bernstein"). It is true that Mayr's species was transferred by Wheeler (1914) to a new genus, Notomyrmica, but the necessary application of the rules of nomenclature forces us nevertheless to reject any homonym, even in the case of so well established a species.

Therefore, I suggest that this species bear the name of the celebrated Myrmecologist. I hope, nevertheless, that in the near future, when a better knowledge of the mainland Macromischa allows us to include them in another genus, Forel's species may again bear its original name.

\section{References}

Forel, A. 1901. Fourmis Mexicaines récoltées par M. le professeur W. M. Wheeler, Ann. Soc. Ent. Bel. 45, pp. 123-136.

Mann, W. M. 1920. Additions to the Ant Fauna of the West Indies and Central America. Bull. Am. Mus. Nat. Hist. 42, pp. 403-439.

Mayr, G. 1868. Die Ameisen des Baltischen Bernstein. Beitr. Naturk. Preuss. physik-ökon. Ges. Königs. 1, $102 \mathrm{pp}$.

Roger, J. 1863. Die Neuaufgeführten Gattungen und Arten meiner Formiciden-Verzeichnisses. Berl. Ent. Zeitschr. pp. 131-214.

Santschi, F. 1931. Fourmis de Cuba et du Panama. Revista de Entomologia, Sao Paulo, Brazil. 1, 3.

Wheeler, W. M. 1914. The Ants of the Baltic Amber. Schrift. physik. ökon. Gesell. Königs., 55, pp. 1-142. 1931. New and Little Known Ants of the Genera Macromischa, Crœsomyrmex and Antillæmyrmex, Bull. M. C. Z. 72, 1. 34 pp. 

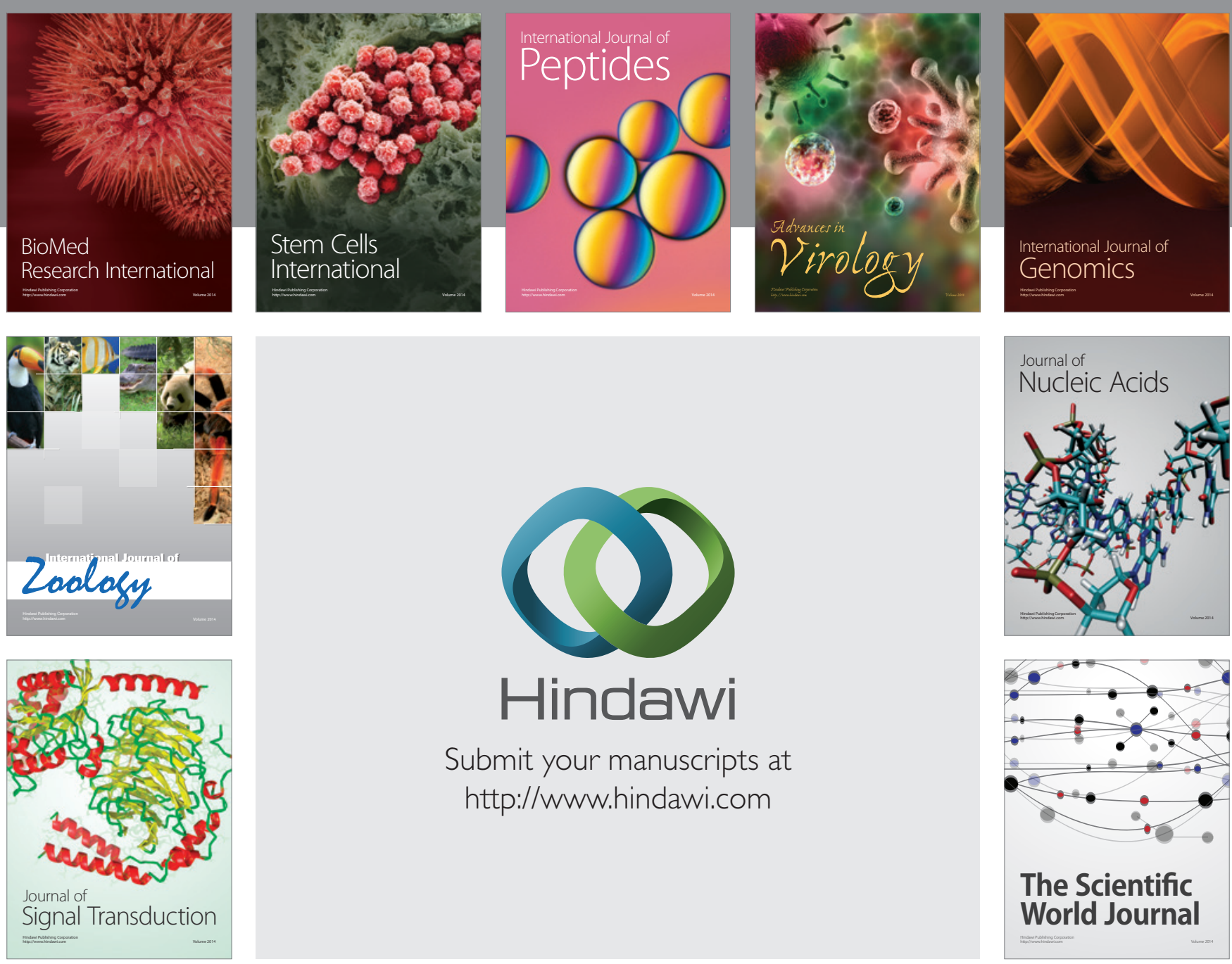

Submit your manuscripts at

http://www.hindawi.com
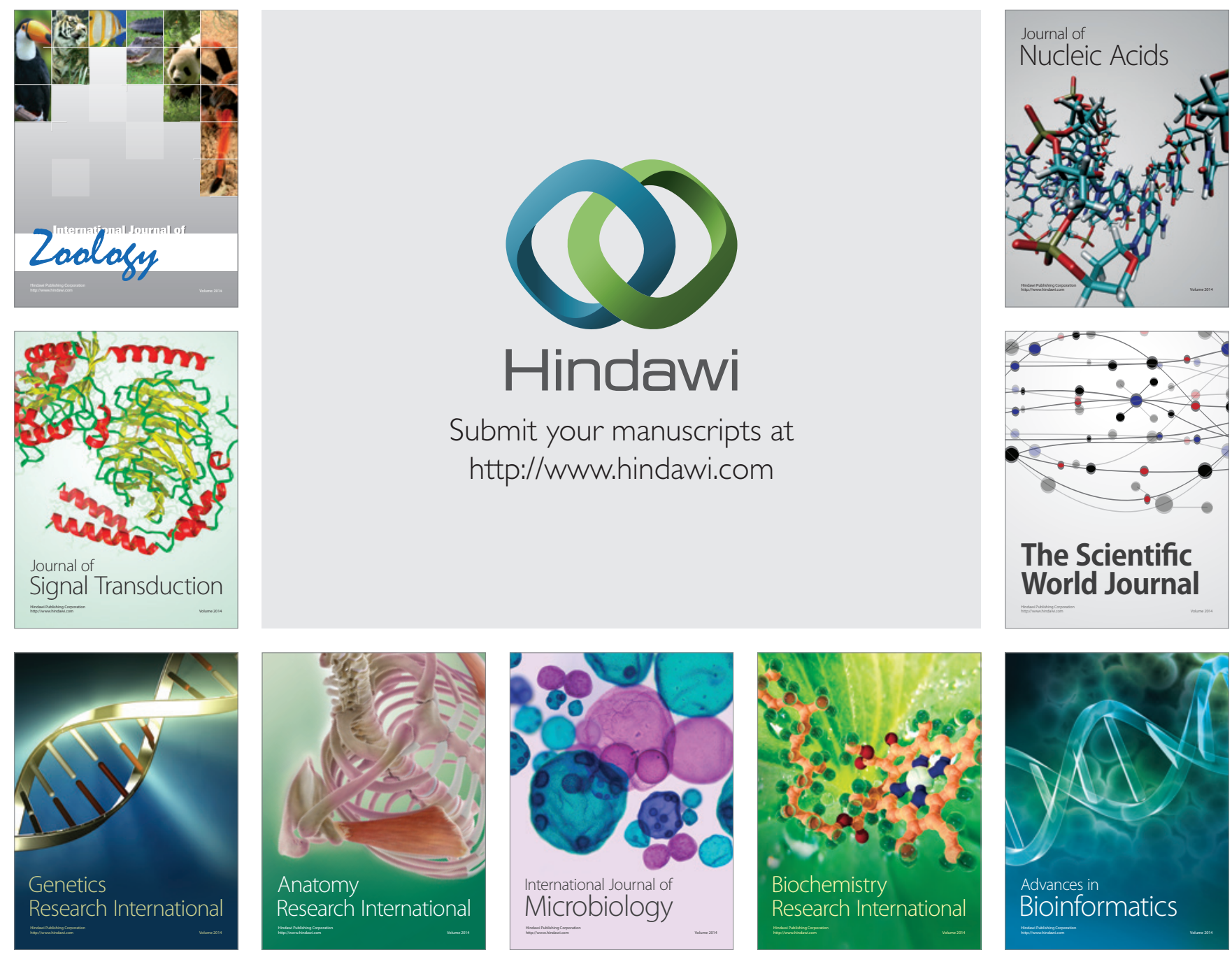

The Scientific World Journal
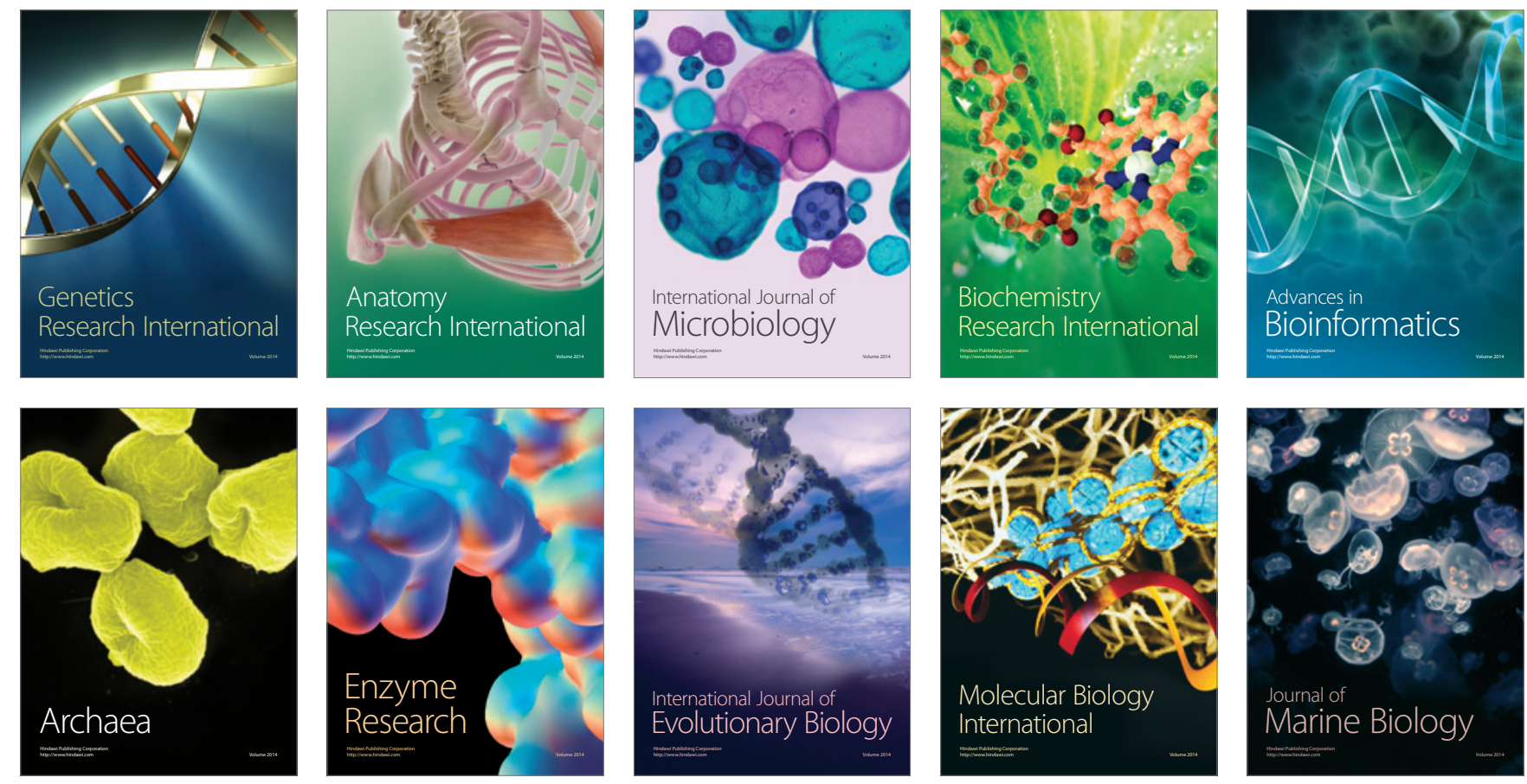